\title{
Study on the Selection of Operation Mode of Green Supply Chain of Agricultural Products
}

\author{
Huang Lu, Hanping Hou, Jianliang Yang \\ School of Economics and Management \\ Beijing Jiaotong University \\ BeiJing, China \\ 1456132487@qq.com
}

\author{
Xue Li, Yue Wang \\ Assistant Engineer \\ Space star technology co., LTD \\ Beijing, China \\ Lixueb2141@163.com
}

\begin{abstract}
Nowadays, with the improved living standards, people have increasing awareness of environmental protection and growing needs of agricultural products. The implementation of green supply chain of agricultural products can provide safe products for consumers, enhancing economic benefits, and have minimal impact on the environment. By applying literature research method, this thesis has set up assessment system of green supply-chain performance of agricultural products and make a research on the selection of operation mode of green supply chain of agricultural products based on supply chain principles. This paper provides a reference for the enterprises to choose the operation mode by constructing the performance evaluation system of green supply chain for agricultural products.
\end{abstract}

Keywords-agricultural products; green supply chain; operation mode; performance evaluation

\section{INTRODUCTION}

As the proverb goes that food is the paramount necessity of people, the diet is the basic need of people's survival and development. Agricultural products have been closely linked with diet and environment, and also have effects on economic growth even the social and national stability. With deteriorated environment pollution and the use of pesticide and chemical fertilizer, the quality of agricultural products is faced with grave challenges and improving the station of food security has become an urgent task. The implementation of green supply chain of agricultural products can guarantee the quality of agricultural products, enhance economic efficiency and cause less waste. Meanwhile, it can reduce the pollution and benefit the ecological construction.

\section{LITERATURE REVIEW}

Zsidisin G A et al. (2001) defined environmental supply chain management and environmental procurement, and then built linkages between environmental procurement and transaction cost analysis [1]. Hagelaar G et al. (2001) researched the integration between life cycle assessment and supply chain. Because of the differences between environmental protection and environmental performance, life cycle assessments should be classified [2].

Handfield R et al. (2005) developed strategic decision framework for environmental supply chain, and then on this basis provided recommendations for the enterprises' supply chain practices, integrating the environmental issues into its supply chain strategy [3].
Yang Haojun (2012) studied the objectives, patterns and mechanisms of the green supply chain for fresh agricultural products [4].Wen Xiuli et al. (2015) proposed green supply chain operation modes based on logistics center and cold chain logistics based on the characteristics of agricultural products [5].

Wu Rong (2015) studied the impact of coordination on the performance of agricultural supply chain, and built the corresponding conceptual, mode based on supply chain coordination theory [6]. Tang Xiaodan (2016) analyzed the structure of the supply chain of fresh agricultural products, and study its operation mode [7].

It can be seen that many domestic and foreign scholars have increased their concern about the environment and researched green supply chain of agricultural products. At present, the researches mainly focus on the structure and performance of supply chain of agricultural products, and the researches on operation mode of supply chain are relatively few. This paper provides a reference for the enterprises to choose the operation mode by constructing the performance evaluation system of green supply chain for agricultural products.

\section{OPERATION MODES OF GREEN SUPPLy CHAIN FOR AgricUlTURAL PRODUCTS}

\section{A. Supply Chain Based on E-commerce Platform (Mode 1)}

E-commerce is developing rapidly, and through the platform, companies can achieve information sharing and reduce market volatility. Downstream enterprises can order through the platform, and farmers can make to order, reducing the impact of bullwhip effect. In addition, it can achieve $\mathrm{O} 2 \mathrm{O}$, reduce intermediate links, decrease inventory costs, and improve distribution efficiency.

\section{B. Supply Chain Based on Cold chain Logistics (Mode 2)}

Owning to the perishable nature of agricultural products, from the farmers to the end consumers, any flaw will do damage to the quality of agricultural products. Therefore, cold chain technology can be introduced to ensure the quality and safety of agricultural products. Collect farmers' agricultural products and carry out simple refrigeration treatment. And then the products can be stored in the cold storage warehouse, through the cold chain distribution products will be assigned to the supermarket, wholesalers, and finally reach the end consumers. 


\section{Supply Chain Based on Distribution Center (Mode 3)}

Scattered agricultural products will be concentrated in the distribution center. Through circulation processing and other operations, it may enhance the added value of the product and the degree of standardization. According to the needs of downstream users, the products can be distributed to the supermarket, wholesalers, and also be directly distributed to consumers.

\section{PERFormance Evaluation Index System}

\section{A. Index Selection}

Considering the influence factors of the performance of the green supply chain, the following dimensions are selected as the first-level indicators of performance evaluation: customer satisfaction, operation status, supply chain flexibility and green indicators.

\section{1) Customer Service Level}

\section{a) Customer satisfaction}

It refers to the extent to which the products or services provided by the firm can meet the needs of the customers.

\section{b) Order response time}

It refers to the time interval from receipt of orders to processing, reflecting the ability to quickly process orders.

\section{c) After-sales service level}

It is not enough for an enterprise to sell the products or service to the customers, but also to provide good after-sales service.

\section{2) Operation Status}

a) Operation cost

Enterprises are very concerned about the cost, which means the capital investment. Excessive costs will narrow the profit margins, and may make enterprises overwhelmed.

\section{b) Profit margins}

The goal of the firm is to make profits. By obtaining profits, enterprises can continue to survive and develop, and then realize their value.

\section{c) Market share}

This indicator reflects the company's proportion of the market, measuring its impact on the market.

\section{3) Supply Chain Flexibility}

\section{a) Information transparency}

Getting more information, companies can better grasp the market dynamics, which is conducive to the development of enterprises and the implementation of operation strategies.

\section{b) Supplier relationship}

Good supplier relationship is the key to success. Moreover, it can maximize the interests of the supply chain.

\section{c) Innovation ability}

Innovation can make companies keep up with the trend, and get more customers and profits.

\section{4) Green Indicators}

a) Product quality

Excellent product quality is the most basic requirement.

b) Resource utilization

The indicator reflects the use of various resources, that is, whether the enterprise maximizes the use of resources to reduce waste.

\section{c) Green degree}

This indicator reflects the green degree of productions and business activities in the supply chain. (Evaluation indicators are shown in TABLE I)

TABLE I. EVALUATION INDICATORS

\begin{tabular}{|c|c|c|}
\hline Aims & $\begin{array}{l}\text { First-level } \\
\text { indicators }\end{array}$ & Secondary-level indicators \\
\hline \multirow{12}{*}{$\begin{array}{c}\text { Supply chain } \\
\text { performance } \\
\text { A }\end{array}$} & \multirow{3}{*}{$\begin{array}{c}\text { Customer } \\
\text { service level } \mathrm{B}_{1}\end{array}$} & Customer satisfaction $\mathrm{C}_{11}$ \\
\hline & & Order response time $\mathrm{C}_{12}$ \\
\hline & & After-sales service level $\mathrm{C}_{13}$ \\
\hline & \multirow{3}{*}{$\begin{array}{l}\text { Operation } \\
\text { status } B_{2}\end{array}$} & Operating costs $\mathrm{C}_{21}$ \\
\hline & & Market share $\mathrm{C}_{22}$ \\
\hline & & Profit margins $\mathrm{C}_{23}$ \\
\hline & \multirow{3}{*}{$\begin{array}{l}\text { Supply chain } \\
\text { flexibility } B_{3}\end{array}$} & Information transparency $\mathrm{C}_{31}$ \\
\hline & & Supplier relationship $\mathrm{C}_{32}$ \\
\hline & & Innovation ability $\mathrm{C}_{33}$ \\
\hline & \multirow{3}{*}{$\begin{array}{c}\text { Green } \\
\text { indicators } \mathrm{B}_{4}\end{array}$} & Product quality $\mathrm{C}_{41}$ \\
\hline & & Resource utilization $\mathrm{C}_{42}$ \\
\hline & & Green degree $\mathrm{C}_{43}$ \\
\hline
\end{tabular}

\section{B. Evaluation Methods}

Analytic hierarchy process (AHP). The basic principle is to establish the hierarchical model among various indicators. Through the comparison of two pairs, determine the relative weight of each element in each level and the relative weight of the total order.

Fuzzy comprehensive evaluation (FCE). Through the establishment of fuzzy evaluation factor set, we endow with the evaluation value, calculate the weighted average, and get the comprehensive evaluation value.

\section{Determination of the Weight of the Index}

1) Construct Judgment Matrix

According to the scale theory (TABLE II ), we can get the judgment matrix: $\mathrm{U}=\left(\mathrm{u}_{\mathrm{ij}}\right)_{\mathrm{n} \times \mathrm{n}}$

TABLE II. MEANING OF JUDGMENT MATRIX SCALE

\begin{tabular}{|c|c|}
\hline Scale value & Meaning \\
\hline 1 & $\mathrm{u}_{\mathrm{i}}$ and $\mathrm{u}_{\mathrm{j}}$ have the same importance \\
\hline 3 & $\mathrm{u}_{\mathrm{i}}$ is slightly more important than $\mathrm{u}_{\mathrm{j}}$ \\
\hline 5 & $\mathrm{u}_{\mathrm{i}}$ is more important than $\mathrm{u}_{\mathrm{j}}$ \\
\hline 7 & $\mathrm{u}_{\mathrm{i}}$ is much more important than $\mathrm{u}_{\mathrm{j}}$ \\
\hline 9 & $\mathrm{u}_{\mathrm{i}}$ is absolutely important than $\mathrm{uj}$ \\
\hline $2,4,6,8$ & represents the intermediate values of adjacent judgment 1-3, \\
\hline Reciprocal & The judgment value of $\mathrm{u}_{\mathrm{j}}$ compared to $\mathrm{u}_{\mathrm{i}}: \mathrm{u}_{\mathrm{ji}}=1 / \mathrm{u}_{\mathrm{ij}}$ \\
\hline
\end{tabular}

2) Calculate the Relative Weights from the Judgment Matrix

Calculate the eigenvector of the judgment matrix and then normalize to satisfy $\sum_{i=1}^{n} W_{i}^{0}=1$. The eigenvector $W_{i}^{0}=$ 
$\left(\mathrm{W}_{\mathrm{i}}^{0}, \mathrm{~W}_{\mathrm{i}}^{0}, \cdots, \mathrm{W}_{\mathrm{i}}^{0}\right)^{\mathrm{T}}$ is the relative importance of each index related to the previous level, that is, the weight vector.

a) Calculate the n-th root:

b) Normalize:

$$
W_{i}=\sqrt[n]{\prod_{i=1}^{n} u_{i j}}(i=1,2, \cdots, n)
$$

$$
\mathrm{W}_{\mathrm{i}}^{0}=\frac{\mathrm{W}_{\mathrm{i}}}{\sum_{\mathrm{i}=1}^{\mathrm{n}} \mathrm{W}_{\mathrm{i}}}
$$

c) Calculate the maximum eigenvalue:

$$
\varepsilon_{\max }=\frac{1}{\mathrm{n}} \sum_{\mathrm{i}=1}^{\mathrm{n}} \frac{\left(\mathrm{UW}^{0}\right)}{\mathrm{W}_{\mathrm{i}}^{0}}
$$

For judgment matrix of different level, the average randomness index correction value R.I. can be introduced to determine the consistency, as shown in TABLE III:

TABLE III. AVERAGE RANDOM CONSISTENCY INDEX

\begin{tabular}{|c|c|c|c|c|c|c|c|c|c|c|}
\hline $\mathrm{n}$ & 1 & 2 & 3 & 4 & 5 & 6 & 7 & 8 & 9 & 10 \\
\hline R.I. & 0 & 0 & 0.52 & 0.89 & 1.12 & 1.26 & 1.36 & 1.41 & 1.46 & 1.49 \\
\hline
\end{tabular}

3) Calculate the consistency index of the judgment matrix to verify its consistency

a) Calculate the random consistency index:

$$
\text { C. I. }=\frac{\varepsilon_{\max }-\mathrm{n}}{\mathrm{n}-1}
$$

b) Calculate the random consistency ratio:

$$
\text { C. R. }=\frac{\text { C.I. }}{\text { R.I. }}
$$

\section{Implementation of FCE}

1) Determine the evaluation factors and level

The vector $F=\left\{f_{1}, f_{2}, \cdots, f_{n}\right\}$ is a set of $n$ evaluation indexes; the vector $E=\left\{e_{1}, e_{2}, \cdots, e_{m}\right\}$ is a set of $m$ evaluation levels.

2) Establish membership degree matrix $R$

Determine the univariate evaluation membership degree vector and form the membership matrix $R=\left\{\begin{array}{ccc}\mathrm{R}_{11} & \cdots & \mathrm{R}_{1 \mathrm{j}} \\ \vdots & \ddots & \vdots \\ \mathrm{R}_{\mathrm{i} 1} & \cdots & \mathrm{R}_{\mathrm{ij}}\end{array}\right\}$.

3) Determine the weight vector

$\mathrm{W}_{\mathrm{F}}$ is the weight vector for evaluating the project metrics. In addition, WE' is the numerical result of the evaluation.

4) Calculate the integrated vector $S$ and the evaluation value $\mu$

$$
\begin{aligned}
& S=W_{F} R \\
& \mu=W_{E}^{\prime} S^{T}
\end{aligned}
$$

\section{Case Analysis}

\section{A. M Company's Profile}

$\mathrm{M}$ company is a large agricultural company, setting up more than 10 branches in Nanjing, Wuhan, Wuhu and others. The company's main business is to provide procurement, warehousing, circulation processing, distribution and other logistics services for a variety of agricultural products.

\section{B. Problems}

- The company has just set up soon, lacking experience in the operation mode of supply chain.

- There are still stock problems which lead to out of stock, product damage and other issues.

\section{Select Operation Mode}

\section{1) $\mathrm{AHP}$}

a) Single order

The judgment matrix at each level is scored by the expert and the relative weights are calculated as follows:

TABLE IV. JUDGMENT MATRIX OF A-B AND WEIGHTS

\begin{tabular}{|c|c|c|c|c|c|c|}
\hline $\mathrm{A}$ & $\mathrm{B}_{1}$ & $\mathrm{~B}_{2}$ & $\mathrm{~B}_{3}$ & $\mathrm{~B}_{4}$ & $\mathrm{~W}_{\mathrm{i}}$ & $\mathrm{W}_{\mathrm{i}}^{0}$ \\
\hline $\mathrm{B}_{1}$ & 1 & 3 & 5 & 2 & 2.34 & 0.48 \\
\hline $\mathrm{B}_{2}$ & $1 / 3$ & 1 & 2 & $1 / 2$ & 0.76 & 0.16 \\
\hline $\mathrm{B}_{3}$ & $1 / 5$ & $1 / 2$ & 1 & $1 / 3$ & 0.43 & 0.09 \\
\hline $\mathrm{B}_{4}$ & $1 / 2$ & 2 & 3 & 1 & 1.32 & 0.27 \\
\multicolumn{8}{c}{ C.I. $=\frac{1}{n} \sum_{i=1}^{n} \frac{\left(U W^{0}\right)}{W_{i}^{0}}=4.0152$} \\
C.R & $=0.0051$ \\
C.I. & $=0.0057<0.1$
\end{tabular}

Similarly, the judgment matrix and weight of the second layer index are as follows:

TABLE V. JUDGMENT MATRIX OF B1-C AND WEIGHTS

\begin{tabular}{|c|c|c|c|c|c|}
\hline $\mathrm{B}_{1}$ & $\mathrm{C}_{11}$ & $\mathrm{C}_{12}$ & $\mathrm{C}_{13}$ & $\mathrm{~W}_{\mathrm{i}}$ & $\mathrm{W}_{\mathrm{i}}{ }^{0}$ \\
\hline $\mathrm{C} 11$ & 1 & 2 & 3 & 2.34 & 0.53 \\
\hline $\mathrm{C} 12$ & $1 / 2$ & 1 & 2 & 1.32 & 0.30 \\
\hline $\mathrm{C} 13$ & $1 / 3$ & $1 / 2$ & 1 & 0.76 & 0.17 \\
\hline \multicolumn{6}{c}{ C. $R .=\frac{\text { C.I. }}{\text { R.I. }}=0.0105<0.1$}
\end{tabular}

TABLE VI. JUDGMENT MATRIX OF B2-C AND WEIGHTS

\begin{tabular}{|c|c|c|c|c|c|}
\hline $\mathrm{B}_{2}$ & $\mathrm{C}_{21}$ & $\mathrm{C}_{22}$ & $\mathrm{C}_{23}$ & $\mathrm{~W}_{\mathrm{i}}$ & $\mathrm{W}_{\mathrm{i}}^{0}$ \\
\hline $\mathrm{C}_{21}$ & 1 & $1 / 2$ & 2 & 1 & 0.30 \\
\hline $\mathrm{C}_{22}$ & 2 & 1 & 3 & 1.82 & 0.54 \\
\hline $\mathrm{C}_{23}$ & $1 / 2$ & $1 / 3$ & 1 & 0.55 & 0.16 \\
\multicolumn{6}{c}{$C . R .=\frac{C . I .}{\text { R.I. }}=0.0093<0.1$}
\end{tabular}

TABLE VII. JUDGMENT MATRIX OF B3-C AND WEIGHTS

\begin{tabular}{|c|c|c|c|c|c|}
\hline $\mathrm{B}_{3}$ & $\mathrm{C}_{31}$ & $\mathrm{C}_{32}$ & $\mathrm{C}_{33}$ & $\mathrm{~W}_{\mathrm{i}}$ & $\mathrm{W}_{\mathrm{i}}{ }^{0}$ \\
\hline $\mathrm{C}_{31}$ & 1 & 2 & 5 & 2.15 & 0.57 \\
\hline $\mathrm{C}_{32}$ & $1 / 2$ & 1 & 4 & 1.26 & 0.33 \\
\hline $\mathrm{C}_{33}$ & $1 / 5$ & $1 / 4$ & 1 & 0.37 & 0.10 \\
\hline \multicolumn{6}{c}{$C . R .=\frac{C . I .}{\text { R.I. }}=0.0243<0.1$}
\end{tabular}

TABLE VIII. JUDGMENT MATRIX OF B4-C AND WEIGHTS

\begin{tabular}{|c|c|c|c|c|c|}
\hline $\mathrm{B}_{4}$ & $\mathrm{C}_{41}$ & $\mathrm{C}_{42}$ & $\mathrm{C}_{43}$ & $\mathrm{~W}_{\mathrm{i}}$ & $\mathrm{W}_{\mathrm{i}}^{0}$ \\
\hline $\mathrm{C}_{42}$ & 1 & 1 & 2 & 1.26 & 0.40 \\
\hline $\mathrm{C}_{42}$ & 1 & 1 & 2 & 1.26 & 0.40 \\
\hline $\mathrm{C}_{43}$ & $1 / 2$ & $1 / 2$ & 1 & 0.63 & 0.20 \\
\hline \multicolumn{6}{c}{ C. R. $=\frac{\text { C.I. }}{\text { R.I. }}=0<0.1$}
\end{tabular}




\section{b) Total sort of C layer (as shown in TABLE IX)}

TABLE IX. TOTAL SORTING OF C LAYER

\begin{tabular}{|c|c|c|c|c|c|}
\hline & $\mathrm{B}_{1}(0.48)$ & $\mathrm{B}_{2}(0.16)$ & $\mathrm{B}_{3}(0.09)$ & $\mathrm{B}_{4}(0.27)$ & $\mathrm{W}_{\mathrm{i}}{ }^{\mathrm{B}}$ \\
\hline $\mathrm{C}_{11}$ & 0.53 & 0 & 0 & 0 & 0.2544 \\
\hline $\mathrm{C}_{12}$ & 0.30 & 0 & 0 & 0 & 0.144 \\
\hline $\mathrm{C}_{13}$ & 0.17 & 0 & 0 & 0 & 0.0816 \\
\hline $\mathrm{C}_{21}$ & 0 & 0.30 & 0 & 0 & 0.048 \\
\hline $\mathrm{C}_{22}$ & 0 & 0.54 & 0 & 0 & 0.0864 \\
\hline $\mathrm{C}_{23}$ & 0 & 0.16 & 0 & 0 & 0.0256 \\
\hline $\mathrm{C}_{31}$ & 0 & 0 & 0.57 & 0 & 0.0513 \\
\hline $\mathrm{C}_{32}$ & 0 & 0 & 0.33 & 0 & 0.0297 \\
\hline $\mathrm{C}_{33}$ & 0 & 0 & 0.10 & 0 & 0.009 \\
\hline $\mathrm{C}_{41}$ & 0 & 0 & 0 & 0.40 & 0.108 \\
\hline $\mathrm{C}_{42}$ & 0 & 0 & 0 & 0.40 & 0.108 \\
\hline $\mathrm{C}_{43}$ & 0 & 0 & 0 & 0.20 & 0.054 \\
\hline
\end{tabular}

\section{2) FCE}

Use the weights determined by the AHP, apply the FCE to judge, and finally the overall evaluation results are obtained. The factor set consists of the indicators of $C$ layer, and the evaluation set is the vector $\mathrm{E}=$ \{better, good, general, poor . Based on the evaluation of the C-level indicators by 20 relevant personnel, the expert scores are obtained by statistical processing of the obtained data (as shown in TABLE 10). The membership matrix R1, R2, and R3 of each operation mode are obtained from each TABLE $\mathrm{X}$.

TABLE X. EXPERT RATING TABLE OF MODE 1/2/3

\begin{tabular}{|c|c|c|c|c|}
\hline $\begin{array}{c}\text { Evaluation } \\
\text { Grade }\end{array}$ & Better(100) & Good(85) & General(70) & Poor(55) \\
$\begin{array}{l}\text { Evaluation } \\
\text { items and } \\
\text { weights }\end{array}$ & & & & \\
\hline $\mathrm{C}_{11}(0.2544)$ & $6 / 3 / 2$ & $6 / 5 / 9$ & $5 / 6 / 6$ & $3 / 6 / 3$ \\
\hline $\mathrm{C}_{12}(0.144)$ & $3 / 5 / 7$ & $6 / 2 / 8$ & $5 / 7 / 2$ & $6 / 6 / 3$ \\
\hline $\mathrm{C}_{13}(0.0816)$ & $10 / 6 / 8$ & $4 / 4 / 2$ & $3 / 5 / 5$ & $3 / 5 / 5$ \\
\hline $\mathrm{C}_{21}(0.048)$ & $5 / 8 / 5$ & $5 / 2 / 6$ & $4 / 7 / 3$ & $6 / 3 / 6$ \\
\hline $\mathrm{C}_{22}(0.0864)$ & $8 / 9 / 9$ & $4 / 1 / 2$ & $4 / 4 / 3$ & $4 / 6 / 6$ \\
\hline $\mathrm{C}_{23}(0.0256)$ & $4 / 10 / 4$ & $6 / 2 / 6$ & $3 / 5 / 3$ & $7 / 3 / 7$ \\
\hline $\mathrm{C}_{31}(0.0513)$ & $8 / 4 / 3$ & $2 / 5 / 6$ & $6 / 6 / 7$ & $4 / 5 / 4$ \\
\hline $\mathrm{C}_{32}(0.0297)$ & $5 / 2 / 8$ & $4 / 9 / 3$ & $6 / 5 / 4$ & $5 / 4 / 5$ \\
\hline $\mathrm{C}_{33}(0.009)$ & $7 / 4 / 6$ & $2 / 8 / 4$ & $4 / 6 / 7$ & $7 / 2 / 3$ \\
\hline $\mathrm{C}_{41}(0.108)$ & $6 / 5 / 3$ & $3 / 8 / 6$ & $4 / 3 / 8$ & $7 / 4 / 3$ \\
\hline $\mathrm{C}_{42}(0.108)$ & $9 / 3 / 1$ & $2 / 6 / 7$ & $4 / 8 / 8$ & $5 / 3 / 4$ \\
\hline $\mathrm{C}_{43}(0.054)$ & $3 / 6 / 2$ & $8 / 7 / 8$ & $5 / 5 / 7$ & $4 / 2 / 3$ \\
\hline
\end{tabular}

$\mathrm{R}_{1}=\left[\begin{array}{llll}0.30 & 0.30 & 0.25 & 0.15 \\ 0.15 & 0.30 & 0.25 & 0.30 \\ 0.50 & 0.20 & 0.15 & 0.15 \\ 0.25 & 0.25 & 0.20 & 0.30 \\ 0.40 & 0.20 & 0.20 & 0.20 \\ 0.20 & 0.30 & 0.15 & 0.35 \\ 0.40 & 0.10 & 0.30 & 0.20 \\ 0.25 & 0.20 & 0.30 & 0.25 \\ 0.35 & 0.10 & 0.20 & 0.35 \\ 0.30 & 0.15 & 0.20 & 0.35 \\ 0.45 & 0.10 & 0.20 & 0.25 \\ 0.15 & 0.40 & 0.25 & 0.20\end{array}\right] \quad R_{2}=\left[\begin{array}{llll}0.15 & 0.25 & 0.30 & 0.30 \\ 0.25 & 0.10 & 0.35 & 0.30 \\ 0.35 & 0.20 & 0.15 & 0.30 \\ 0.40 & 0.10 & 0.15 & 0.35 \\ 0.45 & 0.05 & 0.20 & 0.30 \\ 0.50 & 0.10 & 0.25 & 0.15 \\ 0.20 & 0.25 & 0.30 & 0.25 \\ 0.10 & 0.45 & 0.25 & 0.20 \\ 0.20 & 0.40 & 0.30 & 0.10 \\ 0.25 & 0.40 & 0.15 & 0.20 \\ 0.15 & 0.30 & 0.40 & 0.15 \\ 0.30 & 0.35 & 0.25 & 0.10\end{array}\right] \quad R_{3}=\left[\begin{array}{llll}0.10 & 0.45 & 0.30 & 0.15 \\ 0.35 & 0.40 & 0.10 & 0.15 \\ 0.40 & 0.10 & 0.25 & 0.25 \\ 0.25 & 0.30 & 0.15 & 0.30 \\ 0.45 & 0.10 & 0.15 & 0.30 \\ 0.20 & 0.30 & 0.15 & 0.35 \\ 0.15 & 0.30 & 0.35 & 0.20 \\ 0.40 & 0.15 & 0.20 & 0.25 \\ 0.30 & 0.20 & 0.35 & 0.15 \\ 0.15 & 0.30 & 0.40 & 0.15 \\ 0.05 & 0.35 & 0.40 & 0.20 \\ 0.10 & 0.40 & 0.35 & 0.15\end{array}\right]$

\section{3) Results Analysis}

1. From the results of fuzzy comprehensive evaluation, we can see that the performance evaluation scores of the three modes are $79.357,77.047$ and 78.361 respectively. It can be more intuitive to determine that the mode 1 has the best performance. Therefore, $\mathrm{M}$ company should give priority to select mode 1 .
2. We can visually see the importance of the indicators that affect the operation of the enterprise, which with greater weight are customer satisfaction, order response time, product quality, and green degree. The company can give priority to solve the impact of these indicators, and accelerate the survival and development of enterprises.

3. The relative weight of customer satisfaction is 0.2304 , so special attention should be paid to this. Always take the customer as the starting point, and provide customers with products and services with correct quality and quantity to enhance brand image.

\section{Recommendations}

- Create a good operation environment. Firstly, establish a sound system of laws and regulations for the protection of green products, and supervise related enterprises to promote the standardization. Secondly, strive to develop cold chain and other technologies, to provide technical support.

- Promote modernization of agriculture. Due to social and historical reasons, production technology has also lagged behind the developed countries. Government should focus on promoting agricultural modernization, improving the efficiency of agricultural production.

- Build long-term partnerships. The development of an enterprise is inseparable from the cooperation with others. Therefore, enterprises should establish long-term partnerships, improve the transparency of information, and increase cooperation efforts.

\section{CONCLUSION}

From the perspective of green supply chain management, this paper integrates four factors affecting green supply chain of agricultural products and sets up index systems in four aspects of customer satisfaction, operation status, supply chain flexibility and green indicators. It employs comprehensive assessment to measure and calculate enterprises' overall performance, offering a reference to the optimal operation mode of supply chain. The future study is directed to take more factors into consideration and put forward more comprehensive operating models. Meanwhile, it will further to enhance enterprise performance from the perspective of cost.

\section{References}

[1] Zsidisin G A, Siferd S P. Environmental purchasing: a framework for theory development[J]. European Journal of Purchasing \& Supply Management, 2001, 7(1):61-73.

[2] Hagelaar G J L F, Jack G.A.J. van der Vorst. Environmental supply chain management: using life cycle assessment to structure supply chains[J]. International Food \& Agribusiness Management Review, 2001, 4(4):399-412.

[3] Handfield R, Sroufe R, Walton S. Integrating environmental management and supply chain strategies[J]. Business Strategy and the Environment, 2005, 14(1):1-19.

[4] Yang Haojun. Operation mode and mechanism construction of green supply chain for fresh agricultural products[J]. Logistics Science \& Technology, 2012 (11): 27-31. (In Chinese)

[5] Wen Xiuli, Yu Jun.Study on the operation mode of green agricultural product supply chain[J]. Logistics Science and Technology, 2015, 38 (2): 61-63. (In Chinese) 
[6] WU Rong. Study and prospect of green supply chain coordination and its impact on performance of agricultural products[J]. Journal of Anhui Agricultural Sciences, 2015, 20 (20): 302-304.(In Chinese)

[7] Tang Xiaodan. Research on the transformation of operation mode of fresh supply chain for agricultural products with E - commerce enterprises as the core[J]. Logistics Technology, 2016, 39 (2): 120-122. (In Chinese) 